\title{
STUDIES ON AMINO ACID EXCRETION IN MAN. V. CHRONIC ULCERATIVE COLITIS AND REGIONAL ENTERITIS ${ }^{1}$
}

\author{
By JOSEPH B. KIRSNER, A. LEONARD SHEFFNER, ${ }^{2}$ AND WALTER L. PALMER \\ (From the Frank Billings Medical Clinic, Department of Medicine, University of Chicago, \\ Chicago)
}

(Submitted for publication January 3, 1950; accepted, March 13, 1950)

The depletion of body protein complicating chronic ulcerative colitis and regional enteritis (1) may be attributed to a combination of factors. These include the insufficient intake of food, the increased catabolism of protein during fever and possibly the loss of nitrogen in the tissue fluids, blood and purulent exudate from the diseased bowel; decreased synthesis of protein resulting from concomitant impairment of hepatic function may be a contributory factor. Direct studies of this problem have been made only occasionally. Welch, Adams and Wakefield (2) noted increased fecal outputs of nitrogen and negative nitrogen balances in three patients with ulcerative colitis. Sappington and Bockus (3) obtained evidence of previous protein depletion in five patients with the disease. The large outputs of nitrogen in the ileostomy drainage in four of seven patients with ulcerative colitis (4), the decreased absorption of a protein hydrolysate from closed loops of jejunum (5), and the poor assimilation of glucose from the small intestine (6), as noted in one case, have suggested to various observers the contributory role of an associated dysfunction of the small bowel.

The investigations mentioned were limited to determinations of nitrogen balance and to clinical observations. To interpret more completely the mechanisms involved in the protein depletion, it appeared desirable to supplement the above approach with an analysis of certain individual amino acids in plasma, urine and feces. Three normal persons, three patients with chronic ulcerative colitis and one with regional enteritis were studied. In addition to the nitrogen balance, eight amino acids : leucine, isoleucine, valine, threonine, arginine, histidine, lysine and methionine, were measured microbiologically in the food, plasma, urine,

1 This study was supported in part by grants from the Evaporated Milk Association and the American Dairy Association.

2 Present address : Department of Biological Chemistry, University of Illinois, College of Medicine, Chicago, Ill. and feces. The assimilation of supplemental protein also was investigated in two patients with ulcerative colitis. Attention was directed in this study to the utilization of natural protein by patients with ulcerative colitis and regional enteritis, possible abnormalities in the amino acid content of plasma and urine, and to the fecal outputs of nitrogen and amino acids in the colitis-enteritis group.

\section{METHOD OF STUDY}

Subjects. The study was conducted in the metabolism unit of the Albert Merritt Billings Hospital. The three normal individuals have been described previously (7). The pertinent data on the four patients are as follows:

G.B., clinically mild ulcerative colitis, male, 36 years of age, had had chronic ulcerative colitis for 15 years. The physical examination was normal except for evidence of slight loss of weight. The proctoscopic findings were characteristic. Roentgenologically, the colon between the rectum and hepatic flexure appeared narrowed and stiffened; the mucosal pattern was polypoid. $\mathrm{X}$-rays of the chest and upper gastrointestinal tract were normal. The feces did not contain pathogenic bacteria or parasites. The erythrocyte count was 4.06 million, hemoglobin $11.5 \mathrm{gm}$. and the leukocyte count 5,750. The sedimentation rate, urine analysis, serum electrolytes, calcium, phosphorus, oral glucose tolerance, urea clearance and various tests of hepatic function were normal. The maximum free hydrochloric acid (histamine stimulation) was 90 clinical units. The total plasma proteins, albumin, and globulin were normal. The diarrhea subsided promptly after admission to the hospital, one or two soft-formed stools being passed daily; the benzidine test was negative or occasionally slightly positive. Phenobarbital, $0.03 \mathrm{gm}$., and extract of belladonna, $0.0075 \mathrm{gm}$., were prescribed twice daily. The body temperature remained normal. Height $185 \mathrm{~cm}$., initial weight $75.8 \mathrm{~kg}$., body surface area 2.06 square meters, basal metabolic rate +6 ; basal calories were estimated as 1,940 . The test diet contained carbohydrate 316 , protein 73 and fat 143 gm., 2,843 calories daily. There was no significant change in body weight (loss of $0.9 \mathrm{~kg}$.) during the metabolic period.

J.P., moderately severe ulcerative colitis, male, 22 years of age, had experienced symptoms for slightly more than two years. The past history included rheumatic fever at the age of 13. Physical examination disclosed 
evidence of considerable weight loss and the typical features of mitral stenosis together with aortic insufficiency; the patient was not in cardiac failure at the time of study. The rectal mucosa was coarsely granular and friable. Roentgenologically, the entire colon was narrowed and shortened; the terminal ileum appeared uninvolved. The upper gastrointestinal tract was normal. The heart was moderately enlarged; the lungs were clear. The erythrocyte count was 4.86 million, hemoglobin $13.2 \mathrm{gm}$. and leukocyte count 9,600 ; the differential blood smear contained 46 per cent lymphocytes. The sedimentation rate, nine days before the study, was moderately elevated. 'The feces did not contain pathogenic bacteria or parasites. The patient's serum did not contain agglutinins for typhoid, salmonella, dysentery, or brucella organisms. The urine was normal, as were the serum electrolytes including calcium and phosphorus; renal function, oral glucose tolerance and hepatic function tests were normal. The maximum free hydrochloric acid (histamine stimulation) was 107 clinical units. The total plasma proteins on two occasions were 7.45 and $7.78 \mathrm{gm}$. per cent, the albumin 3.76 and 4.06, and the globulin 3.69 and $3.72 \mathrm{gm}$. per cent. The temperature was elevated slightly, with occasional peaks of $38^{\circ} \mathrm{C}$; ; the pulse rate varied between 70 and 90. Three to five soft-formed or liquid stools were passed daily; the benzidine test later demonstrated the presence of small amounts of occult blood. No medication was given. The daily test diet contained carbohydrate 291, protein 58, and fat $134 \mathrm{gm}$., 2,602 calories. The patient had lost $2 \mathrm{~kg}$. in weight during the preceding week, but his weight did not change during the metabolic period (loss of $0.3 \mathrm{~kg}$.). Height $176 \mathrm{~cm}$., initial weight 58.2 kg., body surface area 1.69 square meters, metabolic rate +4 , basal calories 1,740 .

M.U., clinically severe ulcerative colitis, male, 47 years of age, had experienced chronic recurrent disease for 10 years. The physical examination disclosed evidence of moderate loss of weight and slight abdominal tenderness. The proctoscopic findings were typical of active disease. The feces did not contain pathogenic bacteria or parasites. Roentgenologically, the entire colon appeared involved. $\mathrm{X}$-rays of the chest were normal. The erythrocyte count was 5.12 million, hemoglobin $12.5 \mathrm{gm}$., and leukocyte count 15,800 ; the sedimentation rate was moderately elevated. The urine, the serum electrolytes including calcium and phosphorus, oral glucose tolerance, and tests of hepatic function were normal. The blood urea nitrogen was $17.2 \mathrm{mg}$. per cent; the urea clearance, 75 per cent of normal. The total plasma proteins were $6.03 \mathrm{gm}$. per cent, albumin 3.39, and globulin $2.64 \mathrm{gm}$. per cent. Six to eight loose stools containing gross blood were passed daily. The temperature on three days of the study ranged between 37.4 and $37.8^{\circ} \mathrm{C}$. The test diet contained carbohydrate 270 , protein 65 , and fat $104 \mathrm{gm}$., 2,276 calories. Height $172 \mathrm{~cm}$., initial weight $63.7 \mathrm{~kg}$., body surface area 1.74 square meters, basal metabolic rate +3 , and basal calories 1,590. The body weight did not change significantly (loss of $0.2 \mathrm{~kg}$.), although the patient had lost $2 \mathrm{~kg}$. in the preceding two weeks. Phenobarbital,
$0.03 \mathrm{gm}$., and extract of belladonna, $0.0075 \mathrm{gm}$., were prescribed three times daily.

H.C., moderately severe regional enteritis, male, 16 years of age, had experienced cramping pain in the lower abdomen, anorexia and a loss of 24 pounds in weight during a period of six months; nausea and vomiting had occurred recently. The physical examination was normal. Roentgen examination disclosed evidence of disease in the distal $20 \mathrm{~cm}$. of ileum with possible "skip" areas proximally; the colon was normal. X-rays of the chest and upper gastrointestinal tract were normal. The feces did not contain blood, pathogenic bacteria or parasites. The urine was essentially normal. The erythrocyte count was 4.5 million, hemoglobin $10.0 \mathrm{gm}$; ; the leukocyte count was 8,600 , increasing three weeks later to 14,000 . The sedimentation rate was slightly elevated. The serum electrolytes, glucose tolerance, renal function and hepatic function were normal. The total plasma proteins, albumin, and globulin were normal. The temperature rose daily to 37.4 or $37.5^{\circ} \mathrm{C}$. One to three soft-formed or loose stools were passed daily. Phenobarbital was prescribed in daily doses of 0.015 or $0.03 \mathrm{gm}$. The test diet contained carbohydrate 271 , protein 58 , and fat $124 \mathrm{gm}$., 2,432 calories. Height $172 \mathrm{~cm}$., weight $55.6 \mathrm{~kg}$., body surface area 1.69 square meters, basal metabolic rate -12 , and basal calories 1,610 . The patient lost $8 \mathrm{~kg}$. in weight during the preceding three weeks, but his weight did not change significantly during the metabolic period.

The plasma volume in controls J.D. and R.G.H. measured 2,610 and 2,728 cc., respectively; in patient G.B. 3,456 cc.

\section{DIET}

All subjects received a weighed, bland diet, including high quality proteins such as beef, eggs, and milk. One gm. of protein was given per kilogram of body weight per day. The daily intake of nitrogen approximated minimum requirements for maintenance in normal persons. The values for the controls were: J.D., $7.20 \mathrm{gm}$.; R.G.H., $7.20 \mathrm{gm}$.; and R.S.L., $6.75 \mathrm{gm}$; ; and for the patients: G.B., 6.08 gm.; J.P., 6.11 gm.; M.U., 5.76 gm.; and H.C., $5.51 \mathrm{gm}$. per square meter of body surface area. The daily caloric intake averaged 3,200 for each of the controls; the caloric intakes for the patients were: G.B., 2,840 ; J.P., 2,600; M.U., 2,280; and H.C., 2,430. The diet contained adequate quantities of vitamins and minerals. Two or three gm. of table salt were added daily to the food. Each metabolic period was of six days' duration except in patient H.C., in whom the study was maintained for nine consecutive days; a transitional period of three days' duration for adjustment to the diet preceded each study. The assimilation of whole protein was further investigated in two patients, J.P. and M.U., by supplementing the constant diet with $100 \mathrm{gm}$. of whole egg per day.

The normal subjects continued their usual activity; the patients remained in bed or in a chair. Water was allowed ad libitum; the fluid intake and the urine output were recorded daily. 
TABLE I

Nitrogen intake and output in normal individuals and in patients with chronic ulcerative colitis or regional enteritis

\begin{tabular}{|c|c|c|c|c|c|}
\hline & \multirow{2}{*}{ N Intake } & \multirow{2}{*}{ N Balance } & \multicolumn{3}{|c|}{ Out put of } \\
\hline & & & Urea $\mathbf{N}$ & $\begin{array}{c}\text { Total } \\
\text { urine N }\end{array}$ & Fecal N \\
\hline $\begin{array}{l}\text { Normal Subjects: } \\
\text { J.D. } \\
\text { R.G.H. } \\
\text { R.S.L. }\end{array}$ & $\begin{array}{c}g m . / m^{2} / d a y \\
7.20 \\
7.20 \\
6.75\end{array}$ & $\begin{array}{l}g m . / m^{2} / d a y \\
\\
+0.57 \\
+0.35 \\
+0.65\end{array}$ & $\begin{array}{c}g m . / m^{2} / d a y \\
\\
4.66 \\
4.91 \\
4.38\end{array}$ & $\begin{array}{c}g m . / m^{2} / d a y \\
\\
6.15 \\
6.29 \\
5.57\end{array}$ & $\begin{array}{c}g m . / m^{2} / d a y \\
\\
0.48 \\
0.56 \\
0.53\end{array}$ \\
\hline $\begin{array}{l}\text { Patients: } \\
\text { G.B. } \\
\text { J.P. } \\
\text { M.U. }\end{array} \begin{array}{l}\text { Ulcerative colitis } \\
\text { H.C. }\end{array}$ & $\begin{array}{l}6.08 \\
6.11 \\
5.76 \\
5.51\end{array}$ & $\begin{array}{l}-0.06 \\
-0.04 \\
-2.00 \\
-1.60\end{array}$ & $\begin{array}{l}4.30 \\
3.05 \\
2.28 \\
4.20\end{array}$ & $\begin{array}{l}5.39 \\
4.32 \\
3.27 \\
5.77\end{array}$ & $\begin{array}{l}0.75 \\
1.83 \\
4.49 \\
1.34\end{array}$ \\
\hline
\end{tabular}

The preparation and analysis of the food, plasma, urine, and feces, and the microbiological methods employed for the determination of individual amino acids have been described elsewhere (8). The measurements in food, urine and feces were for the total quantity of each amino acid in acid-hydrolyzed samples. In plasma, the free amino acids were measured in tungstic acid filtrates, prepared according to Hier and Bergeim (9). Total non-protein amino acids were determined on acid-hydrolyzed tungstic acid filtrates. Total nitrogen in the food, urine and feces was measured by a semi-micro Kjeldahl procedure using selenium as a catalyst, urea by a modification of the urease method (10), and free ammonia nitrogen by distillation into boric acid after alkalinization of the sample with potassium carbonate.

\section{RESULTS}

The body weights and the circulating plasma proteins did not change significantly during the metabolic periods. The normal subjects were in slightly positive nitrogen balance. Patients G.B. and $J . P$. were in approximate nitrogen equilibrium; M.U. and H.C. were in slightly negative balance. The daily output of urea nitrogen was normal in G. B. and H. C., diminished in J.P. and M.U. (Table I). The excretion of ammonia nitrogen did not vary significantly. The fecal nitrogen in the colitis-enteritis group consistently exceeded the normal range, as determined in the three healthy controls and in four previously studied patients with peptic ulcer.

The data for amino acids are summarized in Tables II and III. Since the daily intakes were very similar for the controls and the patients, the values are averaged for the entire series. The outputs of each amino acid in the urine and feces and the plasma levels are averaged for the normal group and are tabulated for each patient.

The concentrations of free amino acids in plasma were approximately the same in the two groups.

TABLE II

Amino acid concentrations in plasma of normal individuals and patients with chronic ulcerative colitis or regional enteritis

\begin{tabular}{|c|c|c|c|c|c|c|c|c|c|c|c|c|c|c|}
\hline & \multicolumn{7}{|c|}{ Free amino acids } & \multicolumn{7}{|c|}{ Total non-protein amino acids } \\
\hline & \multicolumn{2}{|c|}{$\begin{array}{c}\text { Normal } \\
\gamma / m l .\end{array}$} & \multicolumn{4}{|c|}{$\begin{array}{l}\text { Ulcerative colitis } \\
\gamma / c c .\end{array}$} & \multirow{2}{*}{$\begin{array}{c}\begin{array}{c}\text { Reg. ent. } \\
\gamma / c c .\end{array} \\
\text { H.C. }\end{array}$} & \multicolumn{2}{|c|}{$\begin{array}{l}\text { Normal } \\
\gamma / c c .\end{array}$} & \multicolumn{4}{|c|}{$\begin{array}{l}\text { Ulcerative colitis } \\
\gamma / c c .\end{array}$} & \multirow{2}{*}{$\frac{\begin{array}{c}\text { Reg. ent. } \\
\gamma / c c .\end{array}}{\text { H.C. }}$} \\
\hline & Average & Range & G.B. & J.P. & M.U. & Average & & Average & Range & G.B. & J.P. & M.U. & Average & \\
\hline $\begin{array}{l}\text { Leucine } \\
\text { Isoleucine } \\
\text { Valine } \\
\text { Threonine } \\
\text { Arginine } \\
\text { Histidine } \\
\text { Lysine } \\
\text { Methionine }\end{array}$ & $\begin{array}{r}29 \\
18 \\
29 \\
27 \\
17 \\
16 \\
26 \\
6\end{array}$ & $\begin{array}{c}20-40 \\
17-21 \\
20-39 \\
19-42 \\
15-19 \\
13-21 \\
24-28 \\
4-7\end{array}$ & $\begin{array}{l}21 \\
11 \\
29 \\
15 \\
20 \\
15 \\
20 \\
-\end{array}$ & $\begin{array}{r}21 \\
13 \\
30 \\
15 \\
29 \\
13 \\
32 \\
5\end{array}$ & $\begin{array}{r}14 \\
21 \\
23 \\
11 \\
20 \\
14 \\
29 \\
7\end{array}$ & $\begin{array}{r}19 \\
15 \\
27 \\
14 \\
23 \\
14 \\
27 \\
6\end{array}$ & $\begin{array}{r}30 \\
16 \\
35 \\
19 \\
20 \\
12 \\
35 \\
4\end{array}$ & $\begin{array}{r}48 \\
32 \\
42 \\
45 \\
33 \\
24 \\
52 \\
6\end{array}$ & $\begin{array}{c}43-52 \\
28-37 \\
39-47 \\
37-54 \\
27-44 \\
22-28 \\
39-69 \\
5-7\end{array}$ & $\begin{array}{l}29 \\
15 \\
36 \\
19 \\
19 \\
13 \\
25 \\
-\end{array}$ & $\begin{array}{l}64 \\
31 \\
56 \\
49 \\
67 \\
23 \\
84 \\
7\end{array}$ & $\begin{array}{l}93 \\
64 \\
63 \\
72 \\
88 \\
30 \\
91 \\
15\end{array}$ & $\begin{array}{l}62 \\
37 \\
52 \\
47 \\
58 \\
22 \\
67 \\
11\end{array}$ & $\begin{array}{r}73 \\
33 \\
51 \\
49 \\
51 \\
21 \\
81 \\
8\end{array}$ \\
\hline
\end{tabular}

Blood drawn simultaneously with close of metabolic period, after an overnight fast 
TABLE III

Intake of amino acids in food and excretion in urine and feces of normal individuals and patients with chronic ulcerative colitis or regional enteritis

\begin{tabular}{|c|c|c|c|c|c|c|c|c|c|c|c|c|c|c|c|}
\hline & \multirow{3}{*}{ Intake } & \multicolumn{7}{|c|}{ Urine } & \multicolumn{7}{|c|}{ Feces } \\
\hline & & \multicolumn{2}{|c|}{$\underset{m g . / m^{2} / d a y}{\text { Normal }}$} & \multicolumn{4}{|c|}{$\begin{array}{l}\text { Ulcerative colitis } \\
m g . / m^{2} / d a y\end{array}$} & \multirow{2}{*}{$\begin{array}{c}\begin{array}{c}\text { Reg. ent. } \\
m g . / m^{2} / \\
\text { day }\end{array} \\
\text { H.C. }\end{array}$} & \multicolumn{2}{|c|}{$\underset{m g . / m^{2} / d a y}{\text { Normal }}$} & \multicolumn{4}{|c|}{$\begin{array}{l}\text { Ulcerative colitis } \\
m g . / m^{2} / d a y\end{array}$} & \multirow{2}{*}{$\begin{array}{c}\begin{array}{c}\text { Reg. ent. } \\
m g . / m^{2} \\
d a y\end{array} \\
\text { H.C. }\end{array}$} \\
\hline & & Average & Range & G.B. & J.P. & M.U. & Average & & Average & Range & G.B. & J.P. & M.U. & Average & \\
\hline $\begin{array}{l}\text { Leucine } \\
\text { Isoleucine } \\
\text { Valine } \\
\text { Threonine } \\
\text { Arginine } \\
\text { Histidine } \\
\text { Lysine } \\
\text { Methionine }\end{array}$ & $\begin{array}{c}\text { mg. } / m^{2} / \\
\text { day } \\
3,150 \\
2,130 \\
2,200 \\
1,530 \\
2,000 \\
1,050 \\
2,600 \\
900\end{array}$ & $\begin{array}{r}12 \\
7 \\
10 \\
32 \\
12 \\
117 \\
50 \\
5\end{array}$ & $\begin{array}{c}6-13 \\
3-8 \\
8-13 \\
28-38 \\
6-15 \\
72-187 \\
33-75 \\
2-7\end{array}$ & $\begin{array}{r}10 \\
5 \\
7 \\
22 \\
14 \\
87 \\
48 \\
3\end{array}$ & $\begin{array}{r}20 \\
8 \\
20 \\
26 \\
17 \\
79 \\
68 \\
8\end{array}$ & $\begin{array}{r}9 \\
6 \\
12 \\
22 \\
17 \\
52 \\
42 \\
2\end{array}$ & $\begin{array}{r}13 \\
6 \\
13 \\
23 \\
16 \\
73 \\
53 \\
4\end{array}$ & $\begin{array}{r}23 \\
12 \\
17 \\
33 \\
25 \\
88 \\
67 \\
8\end{array}$ & $\begin{array}{r}150 \\
120 \\
150 \\
140 \\
120 \\
64 \\
180 \\
50\end{array}$ & $\mid \begin{array}{c}130-170 \\
100-130 \\
130-170 \\
130-150 \\
70-150 \\
50-70 \\
150-220 \\
20-70\end{array}$ & $\begin{array}{r}290 \\
190 \\
200 \\
180 \\
160 \\
90 \\
290 \\
70\end{array}$ & $\begin{array}{l}670 \\
430 \\
580 \\
410 \\
490 \\
250 \\
680 \\
170\end{array}$ & $\begin{array}{r}2410 \\
910 \\
1470 \\
1680 \\
1620 \\
810 \\
2560 \\
340\end{array}$ & $\begin{array}{r}1123 \\
510 \\
750 \\
757 \\
757 \\
383 \\
1177 \\
193\end{array}$ & $\begin{array}{l}545 \\
315 \\
458 \\
328 \\
328 \\
210 \\
536 \\
216\end{array}$ \\
\hline Total & 15,560 & 245 & v & 196 & 246 & 162 & 201 & 273 & 974 & & 1470 & 3680 & 11800 & 5650 & 2936 \\
\hline
\end{tabular}

However, the total non-protein amino acids in plasma were distinctly elevated in two of the three patients with ulcerative colitis and in the one patient with regional enteritis. In M.U., with the most severe colitis, significant increases were noted in all eight amino acids. Leucine, valine, arginine and lysine were elevated in patients J.P. and H.C. The values in G.B., in whom the colitis was quiescent at the time of study, usually were slightly below normal. Thus, increases in the total nonprotein amino acids appeared to correspond with the clinical severity of the disease.

The average outputs of seven of the eight amino acids in the urine were similar in the two groups. The average excretion of histidine was slightly greater in the controls due almost entirely to the larger values in one member of this group. Amino acid excretion tended to be higher in patients J.P. and H.C., but the differences were small. The output of amino acids in the urine of M.U., with severe colitis, was approximately the same as in G.B., with mild colitis. The patterns of excretion likewise were similar (Table III). The patients eliminated slightly higher proportions of leucine, valine, arginine and lysine, and smaller proportions of histidine, but the differences probably are not significant.

The excretion of individual amino acids in the feces was increased in all four patients, significantly in three. The highest outputs were noted in M.U., frequently exceeding the normal averages 10 - to 16 -fold. However, the patterns of excre-

TABLE IV

Percentage composition* of eight amino acids in food and urine and feces of normal individuals and patients with ulcerative colitis and regional enteritis $\dagger$

\begin{tabular}{|c|c|c|c|c|c|c|c|}
\hline & \multirow{2}{*}{ Food } & \multicolumn{3}{|c|}{ Urine } & \multicolumn{3}{|c|}{ Feces } \\
\hline & & Normal & $\begin{array}{l}\text { Ulcerative } \\
\text { colitis }\end{array}$ & $\begin{array}{l}\text { Regional } \\
\text { enteritis }\end{array}$ & Normal & $\begin{array}{l}\text { Ulcerative } \\
\text { colitis }\end{array}$ & $\begin{array}{l}\text { Regional } \\
\text { enteritis }\end{array}$ \\
\hline $\begin{array}{l}\text { Leucine } \\
\text { Isoleucine } \\
\text { Valine } \\
\text { Threonine } \\
\text { Arginine } \\
\text { Histidine } \\
\text { Lysine } \\
\text { Methionine }\end{array}$ & $\begin{array}{c}\text { per cent } \\
20 \\
13 \\
14 \\
10 \\
13 \\
7 \\
17 \\
6\end{array}$ & $\begin{array}{c}\text { per cent } \\
5 \\
3 \\
4 \\
13 \\
5 \\
48 \\
20 \\
2\end{array}$ & $\begin{array}{c}\text { per cent } \\
7 \\
3 \\
6 \\
12 \\
8 \\
36 \\
26 \\
2\end{array}$ & $\begin{array}{c}\text { per cent } \\
8 \\
4 \\
6 \\
12 \\
9 \\
33 \\
25 \\
3\end{array}$ & $\begin{array}{c}\text { per cent } \\
16 \\
12 \\
15 \\
14 \\
12 \\
7 \\
19 \\
5\end{array}$ & $\begin{array}{c}\text { per cent } \\
20 \\
9 \\
13 \\
13 \\
13 \\
7 \\
21 \\
4\end{array}$ & $\begin{array}{c}\text { per cent } \\
19 \\
11 \\
15 \\
12 \\
11 \\
7 \\
18 \\
7\end{array}$ \\
\hline
\end{tabular}

* Per cent of each amino acid contributing to total of the eight amino acids measured.

$\dagger$ All values are group averages except in the single patient with regional enteritis. 
TABLE V

Excretion of nitrogen and amino acids in feces following protein supplementation* of basal diet Two patients with ulcerative colitis $\dagger$

\begin{tabular}{l|c|c}
\hline \hline & Basal period & $\begin{array}{c}\text { Supplemental } \\
\text { period }\end{array}$ \\
\cline { 2 - 3 } & $g m . / \mathrm{m}^{2} /$ day & $g m . / \mathrm{m}^{2} /$ day \\
Food N & 5.81 & 6.84 \\
Fecal N & 3.40 & $3.43 \ddagger$ \\
Urea and ammonia N & 2.98 & 3.72 \\
Total urinary N & 3.60 & 4.35 \\
Food amino acids\& & 14.6 & 17.7 \\
Fecal amino acids & 7.8 & 8.1 \\
\hline
\end{tabular}

* $1.03 \mathrm{gm} . \mathrm{N} / \mathrm{m}^{2} /$ day added to basal diet as whole egg. $\dagger$ Each value is an average of the results in the two patients.

$\ddagger$ The fecal nitrogen decreased slightly in one patient during the supplemental period.

Total of the eight amino acids measured

tion were similar in the two groups (Table IV).

In two patients with ulcerative colitis (J.P. and M.U.) the basal diet later was supplemented with whole egg, providing an additional $1.03 \mathrm{gm}$. of nitrogen per square meter body surface area daily. Approximately 73 per cent of the supplemental nitrogen was excreted as urinary urea and ammonia; 3 per cent was recovered from the feces; 24 per cent apparently was retained. Although the augmented diet contained 21 per cent more of the eight microbiologically measured amino acids than the basal diet, the amino acid output in the feces increased only by 4 per cent, a negligible rise (Table V).

\section{COMMENT}

The present study indicates again that loss of protein in the feces contributes significantly to the nitrogen deficit complicating ulcerative colitis and regional enteritis. The excretion of nitrogen, as might be anticipated, increased with the severity of the disease, and was more pronounced in patient M.U., with the most active colitis. The diminished outputs of total and urea nitrogen in the urine indicate that the catabolism of body protein was not accelerated. The question arises, of course, as to whether or not the data reflect diminished absorption of food and the loss of undigested nutriment, or normal absorption and utilization with excessive elimination of nitrogen in the intestinal content. The metabolism of protein did not appear to be grossly abnormal in the four cases studied. Two of the group were in approximate nitrogen equilibrium, although the intake of pro- tein, regarded as minimally adequate for normal maintenance, was suboptimal for these patients. Positive balances probably could have been achieved in the entire group had larger quantities of protein been administered. It appears noteworthy in this regard that the two patients with ulcerative colitis, given additional high-quality protein, absorbed and converted approximately 73 per cent of the supplemental protein nitrogen to urea and ammonia, retained 24 per cent, and eliminated only 3 per cent in the feces. A study comparing the utilization of protein administered as meat and eggs, skimmed milk powder, a protein hydrolysate, and as evaporated milk, likewise has demonstrated essentially normal utilization of the various protein foods by patients with ulcerative colitis (11). Sappington and Bockus consistently obtained positive nitrogen balances with moderately large intakes of protein, although at least several months of feeding appeared necessary to correct fully the nitrogen deficit. Furthermore, satisfactory repletion of body protein has been noted frequently in patients with ulcerative colitis or regional enteritis after the ingestion of adequate amounts of nitrogen and calories $(12,1 \mathrm{e})$.

The increased losses of nitrogen and amino acids in the feces thus appear to be attributable to the loss of tissue fluids, exudate and blood from the ulcerated, hyperactive bowel. Sappington and Bockus related the excessive fecal excretion of nitrogen in two of their patients to the presence of purulent or bloody exudate rather than to the loss of unabsorbed food. The normal or relatively small increases in the fat content of the feces, observed by these workers and by Welch and his associates, support this view. The excessive fecal outputs of nitrogen and amino acids in patients with ulcerative colitis and regional enteritis emphasize the need for larger intakes of protein.

The normal concentrations of free amino acids in plasma suggest that the absorption, deamination and resynthesis of protein were not grossly impaired. It should be noted, however, that the free amino acid levels may not reflect abnormalities in protein metabolism with sufficient sensitivity. Hier (13), in a study of patients with various diseases, found high values only for tyrosine in four of seven cases with cirrhosis of the liver; except for a slight decrease in histidine, no significant changes were observed in one patient with ulcera- 
tive colitis. The only abnormality we have observed to date among the eight amino acids measured has been an increased concentration of free methionine in the plasma of individuals with severe disease of the hepatic parenchyma (14).

The total non-protein amino acids in plasma were considerably higher than normal in three of the four patients. Godfried (15) has reported increases in the polypeptide content of the serum in ulcerative colitis, the values decreasing as the disease subsided. Similar elevations have been noted by us in peptic ulcer (16) and by others in suppurative conditions, leukemia, severe diabetes, cirrhosis and renal disease. Although the interpretation of these data at present is limited, the increases appear to represent non-specific fluctuations, probably demonstrable in a variety of diseases.

The normal urinary output of amino acids in the colitis-enteritis group tends to exclude any specific defect in amino acid excretion. The amino acid patterns in the urine and feces were the same as observed in the normals. In both groups the amino acids were not excreted in the urine in the same proportion as ingested in the food; a similar dissociation occurs in normal persons and in patients with peptic ulcer (16). The percentage composition of amino acids in the feces was comparable to that of the food (Table IV), as has been noted previously in healthy subjects and in patients with peptic ulcer.

\section{SUMMARY}

1. Nitrogen balances and microbiological measurements of eight individual amino acids in the food, plasma, urine, and feces were obtained in three normal men, three patients with chronic ulcerative colitis, and one with regional enteritis during the administration of a constant diet containing amounts of protein adequate for basal maintenance in normal subjects.

2. The nitrogen balances were slightly positive in the normal subjects, in approximate equilibrium in two patients with ulcerative colitis, and were slightly negative in one patient with severe ulcerative colitis and in one with regional enteritis.

3. The free amino acids in plasma and the excretion of amino acids in the urine were within the normal range.
4. The total non-protein amino acids in plasma were higher than normal in two of the three patients with ulcerative colitis and in the single patient with regional enteritis.

5. The quantities of each of the eight amino acids in the feces were increased significantly in three of the four patients. However, the patterns of amino acid excretion were normal.

6. Two patients with ulcerative colitis, given additional high-quality protein, excreted approximately 73 per cent of the supplemental nitrogen as urinary urea and ammonia, apparently retained 24 per cent, and eliminated only 3 per cent in the feces.

7. The data suggest that

(a) The metabolism of protein is not grossly disturbed in patients with ulcerative colitis and regional enteritis capable of ingesting adequate quantities of food.

(b) Loss of protein in the feces contributes significantly to the nitrogen deficit.

(c) The increased outputs of nitrogen and amino acids in the feces appear attributable to the loss of intestinal secretions, inflammatory exudate, and blood, rather than to unabsorbed food.

Valuable assistance was provided by Miss Blanche Parish, R.N., in the care of the subjects; Miss Minnie Brandt in the preparation and administration of the food; and by Mr. John Grabow and Mrs. Betty Divinsky in the laboratory work.

\section{BIBLIOGRAPHY}

1. a. Mackie, T. T., Studies in ulcerative colitis. Tr. \& Stud., Coll. Physicians, Philadelphia, 1941, 9, 1.

b. Bercovitz, Z., and Page, R. C., Metabolic and vitamin studies in chronic ulcerative colitis. Ann. Int. Med., 1944, 20, 239.

c. Bargen, J. A., The Modern Management of Colitis. C. C. Thomas, Springfield, Ill., 1943.

d. Monaghan, J. F., Ulcerative colitis in: Bockus, H. L., Gastroenterology; Vol. 2, The Small and Large Intestine and Peritoneum, p. 549. W. B. Saunders Co., Philadelphia, 1946.

e. Kirsner, J. B., Palmer, W. L., Maimon, S. N., and Ricketts, W. E., Clinical course of chronic nonspecific ulcerative colitis. J.A.M.A., 1948, 137, 922.

2. Welch, C. S., Adams, M., and Wakefield, E. G., Metabolic studies on chronic ulcerative colitis. J. Clin. Invest., 1937, 16, 161.

3. Sappington, T. S., and Bockus, H. L., Nitrogen me- 
tabolism in chronic idiopathic ulcerative colitis and its therapeutic significance. Ann, Int. Med., 1949, $31,282$.

4. Elsom, K. A., Dickey, F. G., and Chornock, F. W., Functional disturbance of the small intestine in chronic idiopathic ulcerative colitis. Am. J. Digest. Dis., 1942, 9, 74.

5. Zetzel, L., Banks, B. M., and Sagall, E., Intestinal absorption of an amino acid mixture in patients with chronic idiopathic ulcerative colitis and enterocolitis. Am. J. Digest. Dis., 1942, 9, 350.

6. Groen, J., The absorption of glucose from the small intestine in deficiency disease. New England J. Med., 1938, 218, 247.

7. Kirsner, J. B., Sheffner, A. L., and Palmer, W. L., Studies on amino acid excretion in man. III. Amino acid levels in plasma and urine of normal men fed diets of varying protein content. J. Clin. Invest., 1949, 28, 716.

8. Sheffner, A. L., Kirsner, J. B., and Palmer, W. L., Studies on amino acid excretion in man. I. Amino acids in urine. II. Amino acids in feces. J. Biol. Chem., 1948, 175, 107; 176, 89.

9. Hier, S. W., and Bergeim, O., Microbiological determination of free leucine, isoleucine, valine and threonine in dog plasma. J. Biol. Chem., 1945, 161, 717.

10. Van Slyke, D. D., and Cullen, G. E., The determination of urea by the urease method. J. Biol. Chem., 1916, 24, 117.

11. Sheffner, A. L., Kirsner, J. B., and Palmer, W. L., Studies on amino acid excretion in man. VI. Amino acids in plasma, urine and feces during in- gestion of various protein supplements.. (Submitted for publication)

12. a. Madden, S. C., Bassett, S. H., Remington, J. H., Martin, F. J. C., Woods, R. R., and Shull, F. W., Amino acids in therapy of disease. Parenteral and oral administration compared. Surg., Gynec. \& Obst., 1946, 82, 131.

b. Remington, J. H., Bargen, J. A., and Lundy, J. S., Amino acid alimentation in gastrointestinal diseases. Gastroenterology, 1946, 7, 442.

c. Paulson, M., The medical management of ulcerative colitis. Rev. Gastroenterol., 1949, 16, 468.

d. Machella, T. E., and Miller, T. G., Treatment of idiopathic ulcerative colitis by means of a "medical ileostomy" and an orally administered protein hydrolysate-dextri-maltose mixture. Gastroenterology, 1948, 10, 28.

13. Hier, S. W., Studies on the free amino acids of blood and sweat. Ph.D. Thesis, Department of Biological Chemistry, University of Illinois, College of Medicine, 1947.

14. Kirsner, J. B., Sheffner, A. L., and Palmer, W. L., Studies on amino acid excretion in man. VIII. Urinary excretion of nitrogen and amino acids in patients with hepatic disease after intravenous administration of a protein hydrolysate. To be published.

15. Godfried, E. G., Investigations on the polypeptide content of the serum. Biochem. J., 1939, 33, 955.

16. a. Kirsner, J. B., Sheffner, A. L., Palmer, W. L., and Sterling, K., Studies on amino acid excretion in man. IV. Peptic ulcer. J. Clin. Invest., 1950, 29, 867.

b. Cited by Godfried (15). 